\title{
Vaping Sebagai Bagian Dari Budaya Populer (Studi Gaya Hidup pada Perempuan Berhijab Pengguna Vape di Komunitas @ hijabvapersindonesia)
}

\author{
Audrey Andrea Hastan, Suzy S. Azeharie \\ audreyandreatan@yahoo.co.id, suzya@fikom.untar.ac.id
}

Fakultas Ilmu Komunikasi Universitas Tarumanagara

\begin{abstract}
The use of vape is a form of popular culture that is widely practiced by the community. This research examines one of the vape user communities consisting of hijab women who are members of the Instagram group @hijabvapersindonesia. The researchers chose the community as the object of research because the community was the only hijab vapers community in Indonesia and there had never been a previous study examining vape-user consists of women wearing hijab. Based on this explanation, the purpose of this study is to find out the motives of women wearing hijab vape users on Instagram @ hijabvapersindonesia to do vaping activities and to find out what was the reason for vaping being said to be part of popular culture. The type of this research is qualitative descriptive. The research data was collected using observation, interviews, literature studies, and documentation. The data collected were then tested for validity using triangulation of data sources with resource persons from an Islamic religious leader. The results of the study showed that the motive of the vaping activity carried out by the hijab women was due to lifestyle and work. The use of the vape begins with a hobby which then continues to become a job as an influencer.
\end{abstract}

Keywords: Popular Culture, Lifestyle, Instagram, Women Wearing Hijab, Vape

\begin{abstract}
Abstrak
Penggunaan vape merupakan salah satu bentuk budaya populer yang banyak dilakukan oleh masyarakat. Penelitian ini ingin melihat satu komunitas pengguna vape yang terdiri dari para perempuan berhijab yang tergabung dalam grup Instagram @ hijabvapersindonesia karena komunitas tersebut merupakan komunitas hijab vapers satu-satunya di Indonesia. Tujuan penelitian ini adalah untuk mengetahui gaya hidup pada perempuan berhijab pengguna vape di media sosial Instagram. Jenis penelitian ini adalah deskriptif kualitatif. Data penelitian dikumpulkan menggunakan observasi, wawancara, studi kepustakaan, dan dokumentasi. Data yang berhasil dikumpulkan selanjutnya diuji keabsahannya menggunakan triangulasi sumber data dengan narasumber seorang pemuka agama Islam. Hasil penelitian menunjukkan bahwa motif dari kegiatan vaping yang dilakukan oleh para perempuan berhijab tersebut adalah karena gaya hidup dan pekerjaan. Penggunaan vape tersebut diawali dari hobi yang kemudian berlanjut menjadi pekerjaan sebagai seorang influencer.
\end{abstract}

Kata Kunci: Budaya Populer, Gaya Hidup, Instagram, Perempuan Berhijab, Vape

\section{Pendahuluan}

Kebudayaan merupakan suatu hal yang selalu mengalami perkembangan dari waktu ke waktu. Salah satu hasil perkembangan tersebut menciptakan budaya baru yang disebut dengan budaya populer, yaitu sebuah kebudayaan sederhana yang banyak 
diminati dan disukai oleh masyarakat luas. Budaya populer memiliki kaitan yang erat dengan pola pikir rasional dan kemajuan pengetahuan yang menuntun manusia menciptakan sebuah peradaban berbasis alat atau material sehingga menghasilkan gaya hidup yang materialistis atau hedonis (Syah, 2016).

Salah satu contoh budaya populer yang banyak digemari saat ini adalah penggunaan vape (vaping). Kegiatan vaping dilakukan dengan menggunakan alat yang disebut personal vaporizer atau disingkat vape. Vape atau rokok elektrik adalah salah satu jenis dari penghantar nikotin elektronik. Vaping dirancang untuk membantu pecandu rokok tembakau untuk berhenti merokok. Dengan beralih dari rokok tembakau ke vape maka secara perlahan para perokok belajar untuk berhenti merokok (https://hellosehat.com/pusat-kesehatan/berhenti-merokok/bahaya-vape-rokokelektrik diakses pada 6 September 2018 pukul 23:05 WIB).

Seiring dengan semakin populernya kegiatan vaping ini, muncul kelompokkelompok masyarakat yang tergabung dalam komunitas media sosial pengguna vape, salah satunya adalah komunitas pengguna vape yang terdiri dari perempuan berhijab yang tergabung dalam grup Instagram @hijabvapersindonesia. Akun Instagram @ hijabvapersindonesia merupakan media sosial tempat perempuan berhijab yang menggunakan vape untuk saling berkomunikasi dan memiliki kegiatan bersama.

Penulis tertarik untuk meneliti perempuan berhijab yang menggunakan vape tersebut karena penulis ingin mengetahui komunikasi budaya populer yang terjadi dalam gaya hidup mereka dan alasan mereka mengunggah kegiatan tersebut di Instagram. Alasan lainnya adalah karena penelitian pengenai perempuan berhijab yang menggunakan vape belum pernah ada yang meneliti sebelumnya.

Berdasarkan latar belakang penelitian di atas, maka rumusan masalah yang diangkat adalah "apa yang menjadi motif para perempuan berhijab di komunitas @ hijabvapersindonesia menggunakan vape?", dan "mengapa vaping dikatakan sebagai bagian dari budaya populer?" Tujuan penelitian ini adalah untuk mengetahui motif penggunaan vape pada perempuan berhijab di komunitas @ hijabvapersindonesia dan untuk mengetahui alasan mengapa vaping dikatakan sebagai bagian dari budaya populer.

Penelitian ini mendasarkan analisisnya pada teori komunikasi, serta konsep mengenai studi kultural, media sosial, dan gaya hidup. Komunikasi dipahami sebagai sebuah proses pertukaran pesan antara dua pihak atau lebih yang bertujuan untuk menciptakan kesepahaman sehingga dapat memberi makna atau pengaruh terhadap pihak-pihak yang terlibat di dalamnya (Cangara, 2014; Liliweri, 2011; West dan Turner, 2008).

Komunikasi yang dianalisis dalam penelitian ini menggunakan media sosial, khususnya Instagram, yang dijadikan wadah oleh para perempuan berhijab pengguna vape dalam berinteraksi. Perempuan berhijab pengguna vape tersebut memiliki satu komunitas di Instagram yaitu @ hijabvapersindonesia. Fenomena perempuan berhijab pengguna vape tersebut muncul karena mereka menganggap bahwa penggunaan vape merupakan bagian dari gaya hidup modern.

\section{Metode Penelitian}

Penelitian ini menggunakan pendekatan deskriptif kualitatif, yaitu penelitian yang bertujuan untuk memahami fenomena yang dialami oleh subjek penelitian dan menghasilkan data deskriptif dari orang-orang yang diteliti. Pendekatan ini digunakan karena sesuai dengan perumusan masalah penulis yaitu untuk mengetahui motif 
perempuan berhijab pengguna vape melakukan kegiatan vaping dan mengunggahnya di media sosial Instagram. Metode yang digunakan untuk meneliti gaya hidup pada perempuan berhijab pengguna vape di Instagram @hijabvapersindonesia adalah dengan studi kasus.

Subjek dalam penelitian ini adalah perempuan berhijab pengguna vape yang tergabung dalam komunitas Instagram @hijabvapersindonesia. Sementara objek dalam penelitian ini adalah gaya hidup pada perempuan berhijab pengguna vape yang merupakan bagian dari budaya populer. Data penelitian dikumpulkan menggunakan empat metode, yaitu observasi, wawancara, studi kepustakaan, dan dokumentasi.

Data yang berhasil dikumpulkan selanjutnya diuji keabsahannya menggunakan triangulasi sumber data dan dianalisis menggunakan analisis kualitatif sesuai tahapan analisis yang dikemukakan oleh Bungin (2012), yaitu pengumpulan data, reduksi data, penyajian data, dan penarikan kesimpulan.

\section{Hasil Temuan dan Diskusi}

Temuan penelitian menunjukkan bahwa para perempuan berhijab pengguna vape yang menjadi anggota dari grup Instagram @ hijabvapersindonesia merasa bahwa penggunaan vape termasuk ke dalam gaya hidup yang tidak bertentangan dengan agama serta tidak memiliki hubungan dengan kewajiban menggunakan hijab. Meskipun mendapatkan kritikan atau komentar negatif dari masyarakat, namun para perempuan berhijab tersebut tetap merasa tidak bersalah karena vape bukanlah rokok, serta penggunaannya termasuk hak pribadi.

Temuan penelitian juga menyatakan bahwa motif yang mendasari penggunaan vape dan mengunggahnya di Instagram adalah hobi, yaitu hobi untuk melakukan triktrik vape untuk difoto atau direkam dalam video, untuk kemudian dibagikan lewat Instagram. Berawal dari hobi, selanjutnya penggunaan vape tersebut menjadi pekerjaan ketika terdapat perusahaan vape yang melihat dokumentasi trik-trik vape di Instagram dan menawari beberapa perempuan berhijab yang menjadi subjek penelitian ini untuk menjadi influencer vape.

\section{Komunikasi}

Analisa penulis terhadap penelitian ini adalah bahwa perempuan berhijab pengguna vape yang tergabung di dalam komunitas Instagram @ hijabvapersindonesia saling berkomunikasi satu dengan yang lainnya baik secara tatap muka maupun melalui media sosial Instagram. Anggota komunitas @ hijabvapersindonesia yang tersebar di beberapa kota di Indonesia dapat saling terhubung walaupun terpisahkan oleh lokasi. Para anggota komunitas @hijabvapersindonesia biasa saling berkomunikasi melalui grup chat di media sosial Line.

Melalui komunikasi yang dilakukan di media sosial Line dan Instagram, para anggota komunitas @ hijabvapersindonesia dapat saling berbagi dan bertukar ide, informasi serta pengetahuan. Dengan kata lain, penulis mengartikan bahwa komunikasi merupakan komponen penting dalam kegiatan yang dilakukan oleh perempuan berhijab yang bergabung di komunitas@ @ hijabvapersindonesia. Melalui komunikasi, mereka dapat saling berbagi dan bertukaran ide, informasi dan pengetahuan. Hal ini sejalan dengan Alo Liliweri dalam buku yang berjudul Komunikasi Serba Ada Serba Makna yang menyatakan bahwa komunikasi adalah proses pembagian dan pertukaran ide, informasi, pengetahuan, sikap di antara dua atau lebih orang yang mempunyai dan menggunakan tanda serta simbol-simbol yang sama. 


\section{Budaya Populer}

Menurut Husni Thamrin, budaya populer merupakan budaya yang populer di zamannya yang membuat orang mudah mengikuti dan menirunya karena menunjukan sisi yang menyenangkan. Husni Thamrin juga mengatakan bahwa vaping merupakan bagian dari budaya populer karena merupakan bagian dari gaya hidup (wawancara dengan Husni Thamrin di masjid Bahrul Huda, Jakarta pada tanggal 23 November 2018 pukul 12.35).

Penulis menganalisa bahwa yang dikatakan Husni Thamrin mengenai budaya populer sesuai dengan yang dikatakan Burhan Bungin dalam buku yang berjudul Sosiologi Komunikasi bahwa budaya populer merupakan budaya yang lebih banyak memperlihatkan sisi hiburan serta mengesankan sisi yang lebih konsumtif serta dapat disimpulkan bahwa vaping merupakan wujud dari budaya populer karena budaya populer berkaitan erat dengan gaya hidup.

Penulis menganalisa bahwa vaping merupakan gaya hidup yang menjadi bagian dari budaya populer, yaitu budaya yang lebih banyak memperlihatkan sisi hiburan serta mengesankan sisi yang lebih konsumtif serta dapat disimpulkan bahwa vaping merupakan wujud dari budaya populer karena budaya populer berkaitan erat dengan gaya hidup. Hal ini sejalan dengan yang dikatakan Burhan Bungin dalam buku yang berjudul Sosiologi Komunikasi bahwa budaya populer berkaitan erat dengan budaya massa, terutama yang dihasilkan oleh media massa.

\section{Hubungan Komunikasi dan Budaya}

Menurut Husni Thamrin, budaya populer dan komunikasi saling berhubungan karena kegiatan vaping tersebut tidak dapat terlepas dari kegiatan komunikasi. Hal ini beliau katakan karena semua kegiatan yang dilakukan oleh para perempuan berhijab tersebut tidak dapat terlepas dari komunikasi (wawancara dengan Husni Thamrin di masjid Bahrul Huda, Jakarta pada tanggal 23 November 2018 pukul 12.35).

Komunikasi dan budaya terjalin atas pemberian makna sesuai dengan yang terjadi pada perempuan berhijab pengguna vape tersebut. Para perempuan berhijab pengguna vape tersebut memberikan makna bahwa komunikasi dan budaya memiliki ketergantungan karena kegiatan yang mereka lakukan selalu melibatkan kegiatan komunikasi dan kegiatan tersebut merupakan bagian dari budaya yaitu budaya populer.

Komunikasi dan kebudayaan merupakan dua konsep yang tidak dapat dipisahkan. Hal ini penulis katakan karena komunikasi merupakan faktor utama yang menjadi penghubung antar anggota @hijabvapersindonesia dalam menjalin hubungannya satu sama lain.

\section{Hubungan Media Sosial dan Perempuan Berhijab Pengguna Vape}

Media sosial Instagram merupakan suatu media atau tempat berkumpulnya para perempuan berhijab yang menggunakan vape. Perempuan berhijab pengguna vape tersebut memiliki suatu komunitas di Instagram yang bernama @ hijabvapersindonesia. Melalui akun@hijabvapersindonesia, perempuan berhijab pengguna vape tersebut saling berbagi informasi tentang kegiatan vaping serta saling berkumpul untuk melakukan kegiatan vaping bersama.

Lebih lanjut, media sosial memiliki hubungan yang erat dengan para perempuan berhijab pengguna vape karena kegiatan yang dilakukan oleh perempuan berhijab pengguna vape tersebut selalu diunggah di media sosial Instagram. Selain itu, para 
anggota@hijabvapersindonesia saling berkomunikasi satu sama lain melalui media sosial Line.

\section{Gaya Hidup Perempuan Berhijab Pengguna Vape}

David Chaney dalam bukunya yang berjudul Lifestyle mendefinisikan gaya hidup sebagai ciri dari sebuah dunia modern atau bisa juga disebut modernitas. Siapapun yang hidup dalam masyarakat modern akan menggunakan gagasan tentang gaya hidup untuk menggambarkan tentang modernitas. Seiring dengan perkembangan zaman maka diikuti pula dengan perkembangan gaya hidup (Chaney, 1996).

Menurut Philip Kotler dalam buku yang berjudul Manajemen Pemasaran, lifestyle atau biasa disebut gaya hidup adalah pola hidup seseorang di dunia yang mengekspresikan dirinya melalui aktivitas, minat dan opininya. Gaya hidup menggambarkan keseluruhan diri seseorang dalam berinteraksi dengan lingkungannya (Kotler, 2002).

Sementara itu Catur Rismiati dan Bondan Suratno dalam buku yang berjudul Pemasaran Barang dan Jasa menjelaskan lifestyle atau gaya hidup adalah pola hidup seseorang dalam kehidupan sehari-hari yang dinyatakan dalam kegiatan, minat dan pendapat yang bersangkutan karena gaya hidup mencerminkan keseluruhan pribadi yang berinteraksi dengan lingkungan (Rismiati dan Suratno, 2001).

Menurut Husni Thamrin, kegiatan vaping yang dilakukan oleh para perempuan berhijab tersebut merupakan bagian dari gaya hidup karena pada masyarakat modern mudah bagi seseorang untuk mengikuti sesuatu yang sedang tren saat ini. Husni Thamrin berpendapat bahwa perempuan berhijab pengguna vape tersebut melakukan kegiatan vaping karena sedang menjadi tren saat ini sehingga kegiatan tersebut diikuti oleh banyak orang salah satunya adalah komunitas perempuan berhijab pengguna vape tersebut (wawancara dengan Husni Thamrin di masjid Bahrul Huda, Jakarta pada tanggal 23 November 2018 pukul 12.35).

Penulis menganalisa bahwa kegiatan vaping yang dilakukan oleh perempuan berhijab pengguna vape merupakan bagian dari gaya hidup karena berdasarkan hasil observasi yang peneliti lakukan, mereka melakukan kegiatan vaping untuk berinteraksi dengan lingkungannya. Hal ini sejalan dengan pendapat Kotler yang mengatakan bahwa gaya hidup menggambarkan keseluruhan diri seseorang dalam berinteraksi dengan lingkungannya

Selain itu, penulis juga menganalisa bahwa pendapat Husni Thamrin sejalan dengan yang dikatakan David Chaney. Husni Thamrin mengatakan bahwa kegiatan vaping yang dilakukan oleh para perempuan berhijab pengguna vape tersebut merupakan bagian dari gaya hidup karena pada masyarakat modern mudah bagi seseorang untuk mengikuti sesuatu yang sedang tren saat ini. Sementara David Chaney mengatakan bahwa gaya hidup merupakan ciri dari sebuah dunia modern dan siapapun yang hidup dalam masyarakat modern akan menggunakan gagasan tentang gaya hidup untuk menggambarkan tentang modernitas.

\section{Hubungan Vape dengan Agama dan Budaya}

Menurut Abmi Handayani dalam buku yang berjudul Perempuan Berbicara Kretek, seorang perempuan yang memutuskan untuk menggunakan hijab harus paham dengan implikasi pada perilaku. Hijab tidak sekadar menjadi penutup aurat, tetapi juga dimaknai sebagai pengatur perilaku agar sesuai dengan ajaran agama Islam (Handayani, 2012). 
Masih dalam buku yang sama, Abmi Handayani mengatakan bahwa rokok digunakan sebagai simbol perilaku buruk yang selalu dirujuk dengan budaya barat dan kerap dianggap sebagai produk dari budaya luar. Untuk masyarakat Indonesia, rokok selalu dianggap sebagai budaya barat yang tidak cocok dengan budaya timur yang mengedepankan nilai-nilai budaya dan agama (Handayani, 2012).

Husni Thamrin menjelaskan bahwa hijab merupakan kewajiban seorang perempuan Muslim, dan kegiatan vaping yang dilakukan oleh perempuan yang berhijab sebenarnya tergantung pada akhlak dan pribadi masing-masing. Husni Thamrin menganggap hal tersebut bukan sesuatu yang aneh karena di abad modern ini kegiatan seperti merokok ataupun vaping merupakan sesuatu yang wajar. Bahkan di negara-negara Arab pun banyak ditemukan hal seperti itu (wawancara dengan Husni Thamrin di masjid Bahrul Huda, Jakarta pada tanggal 23 November 2018 pukul 12.35).

Menurut Husni Thamrin, merokok atau vaping merupakan suatu kebiasaan yang sudah menjadi gaya hidup. Saat ini vape dianggap sebagai sebuah trend. Husni mengatakan bahwa perempuan yang berhijab dan menggunakan vape sebenarnya terlihat karakter dan akhlaknya. Perempuan tersebut akan terlihat seperti perempuan yang tidak benar dalam arti yang negatif. Vape atau rokok merupakan sesuatu yang hukumnya makruh, yaitu sesuatu yang diperbolehkan namun tidak disukai oleh Sang Maha Pencipta karena tidak bermanfaat (wawancara dengan Husni Thamrin di masjid Bahrul Huda, Jakarta pada tanggal 23 November 2018 pukul 12.35).

Penulis menganalisa bahwa yang dikatakan Husni Thamrin sejalan dengan yang dikatakan Abmi Handayani dalam buku yang berjudul Perempuan Berbicara Kretek bahwa dalam agama Islam sebenarnya tidak ada dalil yang menyatakan bahwa merokok merupakan perbuatan yang dilarang, namun sekarang merokok dijadikan makruh yaitu sebuah status hukum terhadap suatu aktivitas dalam dunia Islam. Hal ini terjadi lebih dikarenakan pertimbangan manfaat dan akibatnya, bukan salah atau benarnya. Pada perempuan berhijab, perilaku merokok adalah perilaku yang tidak sesuai dengan apa yang dimaknakan pada hijab.

Husni Thamrin mengatakan bahwa vape bukan merupakan sesuatu yang salah karena sebenarnya tidak ada larangan yang mengharamkan vape di dalam Al-Quran. Jadi sebenarnya hal tersebut boleh saja dilakukan tergantung persepsi dan pendapat masing-masing individu. Namun bagi Husni Thamrin sendiri, ia mengharamkan kegiatan vaping tersebut karena menurut beliau vape tidak memiliki manfaat yang baik untuk kesehatan. Hal ini bertentangan dengan yang dikatakan oleh informan Arin dan informan Deva bahwa menurut mereka kegiatan vaping berfungsi untuk menghentikan kebiasaan merokok yang mereka nilai lebih berbahaya.

Penulis menganalisa bahwa pendapat setiap orang tentang kegiatan vaping tentu berbeda-beda. Informan Deva berpendapat bahwa vaping merupakan hal yang positif karena dapat menghentikan kegiatan merokok. Informan Arin juga berpendapat bahwa vaping bukan merupakan hal yang negatif karena tidak memiliki efek yang berbahaya seperti merokok dan tidak meninggalkan bau yang tidak enak. Sementara Husni Thamrin mengatakan bahwa walaupun tidak memiliki efek yang berbahaya seperti rokok dan tidak ada larangannya di dalam Al-Quran, tetap saja beliau mengharamkan kegiatan vaping tersebut karena menurut beliau kegiatan vaping merupakan kegiatan yang tidak bermanfaat. Jadi, di luar boleh atau tidaknya, Husni Thamrin menyarankan sebaiknya tidak melakukan kegiatan seperti vaping tersebut karena tidak memiliki manfaat. 


\section{Simpulan}

Kegiatan yang dilakukan oleh para perempuan berhijab pengguna vape tersebut merupakan bagian dari gaya hidup karena gaya hidup merupakan ciri dari masyarakat modern yang mudah mengikuti sesuatu yang sedang tren saat ini. Gaya hidup yang terjadi pada perempuan berhijab pengguna vape tersebut merupakan bagian dari budaya populer karena budaya populer berkaitan dengan budaya massa khususnya media massa dalam hal ini media sosial Instagram. Vaping dikatakan merupakan bagian dari budaya populer karena vaping merupakan gaya hidup yang terjadi pada perempuan berhijab di komunitas @ @ijabvapersindonesia. Alasan para perempuan berhijab tersebut menggunakan vape pada awalnya adalah sekedar hobi. Kemudian hobi tersebut berkembang menjadi pekerjaan sebagai seorang influencer, dan dalam hukum agama Islam, kegiatan vaping bukan merupakan sesuatu yang salah karena tidak ada ayat dalam Al-Quran yang melarang penggunaan vaping. Namun vaping dijadikan sebagai makruh atau sebuah status hukum terhadap suatu aktivitas dalam dunia Islam karena pertimbangan manfaat dan akibatnya, bukan salah atau benarnya.

\section{Ucapan Terima Kasih}

Penelitian ini tidak dapat terlaksana dengan baik jika tidak ada dukungan dari berbagai pihak, baik dari Deva, Arin, Vitha dan Husni Thamrin selaku narasumber; Suzy S. Azeharie, M.A., M.Phil., selaku dosen pembimbing dan pihak lain yang tidak dapat penulis sebutkan namanya satu-satu. Oleh karena itu, pada bagian akhir jurnal ini penulis mengucapkan terima kasih banyak pada seluruh pihak tersebut.

\section{Daftar Pustaka}

Bungin, Burhan. (2012). Analisis Data Penelitian Kualitatif. Jakarta: Raja Grafindo Persada.

Cangara, Hafield. (2014). Perencanaan dan Strategi Komunikasi. Jakarta: PT Raja Grafindo Persada.

Chaney, David. (1996). Lifestyles: Sebuah Pengantar Komprehensif. Yogyakarta: Jalasutra

Handayani, Abmi. (2012). Perempuan Berbicara Kretek. Jakarta: Indonesia Berdikari

https://hellosehat.com/pusat-kesehatan/berhenti-merokok/bahaya-vape-rokokelektrik diakses pada 6 September 2018 pukul 23.05 WIB.

Liliweri, Alo. (2011). Komunikasi Serba Ada Serba Makna. Jakarta: Kencana.

Rismiati, C. \& Suratno, B. (2001). Pemasaran Barang dan Jasa. Yogyakarta: Kanisius.

Syah, Dedi Kurnia. (2016). Komunikasi Lintas Budaya Memahami Teks Komunikasi, Media, Agama dan Kebudayaan Indonesia. Bandung: Simbiosa Rekatama Media.

West, Richard dan Lynn H. Turner. (2008). Pengantar Teori Komunikasi: Analisis dan Aplikasi. (Buku 1, Edisi 3). Terjemahan Maria Natalia. 